UDC 621.396.677.8

\title{
CHARACTERISTICS OF VIBRATOR ARRAYS DIRECTIVITY ON HARMONICS OF MAIN FREQUENCY
}

\author{
Tsaliev T.A., Vakarchuk A.O. \\ O.S. Popov Odessa National Academy of Telecommunications, \\ 1 Kuzhechna St., Odessa, 65029,Ukraine. \\ sunny120606@gmail.com
}

\section{ХАРАКТЕРИСТИКИ СПРЯМОВАНОСТІ ВІБРАТОРНИХ АНТЕННИХ РЕШІТОК НА ГАРМОНІКАХ РОБОЧОЇ ЧАСТОТИ}

\author{
Цалісв Т.А., Вакарчук А.О.
}

Одеська национальна академія зв'язку ім.О.С. Попова, 65029, Украӥна, м. Одеса, вул. Кузнечна, 1. sunny120606@gmail.com

\section{ХАРАКТЕРИСТИКИ НАПРАВЛЕННОСТИ ВИБРАТОРНЫХ АНТЕННЫХ РЕШЕТОК НА ГАРМОНИКАХ РАБОЧЕЙ ЧАСТОТЫ}

\author{
Цалиев Т.А., Вакарчук А.А.
}

\author{
Одесская национальная академия связи им. А.С. Попова, \\ 65029, Укарина, г. Одесса, ул. Кузнечная, 1. \\ sunny120606@gmail.com
}

\begin{abstract}
Antenna patterns representing dependences of the directivity factor (DF) on angular coordinates for arrays formed from Yagi-Uda aerials are considered and discussed. The results of computer modelling are based on the decision of integral equations by the method of moments. Patterns that represent dependences of the coefficient of the directivity factor (DF) for an array and her elements from angular coordinates are counted on fundamental frequency and four harmonics. The data obtained confirmed the validity of the assumptions that the directivity properties of vibrator antenna arrays can significantly affect the EMC conditions for harmonics of the fundamental frequency. At these frequencies, several main maxima appear in the radiation patterns, the level of directivity in which may even exceed the maximum directivity in the main lobe at the fundamental frequency. The DF patterns shown in the article refer to the case of inphase excitation of the active elements of the array (without supply lines). However, in the presence of such lines with sequential or mixed power supply circuits, the dependence of the directivity on the angular coordinates can change significantly. The presence of bandpass filters in the input and output stages of the radar will make it possible to largely suppress the levels of harmonic interference, however, if these filters are made on the basis of transmission line segments, their parameters at harmonic frequencies may be insufficient. Further research can be aimed at studying the spatial characteristics and directivity of vibrator antenna arrays based on wave channel antennas with an increased number of passive vibrators, as well as with various power supply and filtering schemes.
\end{abstract}

Key words: directivity, antenna array, wave channel, operating frequency, loop vibrator.

Анотація. Розглянуті та обговорюються характеристики спрямованості антенних решіток, побудованих з триелементних антен типу "хвильовий канал". Результати комп'ютерного моделювання основні на рішенні інтегральних рівнянь методом моментів. Надані діаграми відображають залежності коефіцієнта спрямованої дії (КСД) для антенної решітки та її елементів від кутових координат, які розраховані на основній частоті і чотирьох ії гармоніках. Отримані дані підтвердили обґрунтованість припущень, що властивості спрямованості вібраторних антенних решіток можуть помітно вплинути на умови ЕМС для гармонік основної частоти. На цих частотах в діаграмах спрямованості з'являються

Tsaliev T.A., Vakarchuk A.O.

Characteristics of vibrator arrays directivity on harmonics of main frequency 
кілька головних максимумів, рівень КСД в яких може навіть перевищувати максимум КСД в головному пелюстку на основній частоті. Показані у статті діаграми КСД відносяться до випадку синфазного збудження активних елементів решітки (без ліній живлення). Однак за наявності таких ліній зі схемами живлення послідовного або змішаного типу залежності КСД від кутових координат можуть істотно змінитися. Наявність смугових фрільтрів у вхідних і вихідних каскадах РЛС дасть можливість багато в чому придушити рівні гармонійних завад, однак, якщо ці фільтри виконані на основі відрізків ліній передачі їх параметри на частотах гармонік можуть виявитися недостатніми. Подальші дослідження можуть бути спрямовані на дослідження просторових характеристик і КСД вібраторних антенних решіток на основі антен типу «хвильовий канал» зі збільшеним числом пасивних вібраторів, а також за різних схем живлення і фрільтрації.

Ключові слова: коефіцієнт спрямованої дії, антенна решітка, хвильовий канал, робоча частота, петльовий вібратор.

Аннотация. Рассмотрены и обсуждаются характеристики направленности антенных решеток, построенных из трехэлементных антенн типа «волновой канал». Результаты компьютерного моделирования основаны на решении интегральных уравнений методом моментов. Приведенные диаграммы отображают зависимости коэффициента направленного действия (КНД) для антенной решетки и ее элементов от угловых координат, рассчитаные на основной частоте и четырех ее гармониках. Полученные данные подтвердили обоснованность предположений, что свойства направленности вибраторных антенных решеток могут заметно повлиять на условия ЭМС для гармоник основной частоты. На этих частотах в диаграммах направленности появляются несколько главных максимумов, уровень КНД, в которых может даже превышать максимум КНД в главном лепестке на основной частоте. Показанные в статье диаграммы КНД относятся к случаю синфразного возбуждения активных элементов решетки (без линий питания). Однако, при наличии таких линий со схемами питания последовательного либо смешанного типа зависимости КНД от угловых координат могут существенно измениться. Наличие полосовых фильтров во входных и выходных каскадах РЛС даст возможность во многом подавить уровни гармонических помех, однако, если эти фрильтры выполнены на основе отрезков линий передачи их параметры на частотах гармоник могут оказаться недостаточными. Дальнейшие исследования могут быть направлены на исследование пространственных характеристик и КНД вибраторных антенных решеток на основе антенн типа «волновой канал» с увеличенным числом пассивных вибраторов, а также при различных схемах питания и фильтрации.

Ключевые слова: коэффициент направленного действия, антенная решетка, волновой канал, рабочая частота, петлевой вибратор.

The development of worldwide communications is accompanied by the emergence and implementation of new technical solutions, such as mobile networks $5 G$ [1] and numerous VHF radars.

Moreover, surveillance radar stations (radars) of the meter wavelength range and existing television channels, as well as mobile communication networks of the decimeter wavelength range, are potentially capable of creating mutual interference at the frequencies of the fundamental radiation and reception harmonics.

In any radio electronic device (RED), the characteristics of receiving and transmitting antennas, in particular, have a great influence on the quality indicators. The characteristics of antennas in the operating frequency band, such as gain, radiation pattern (RP) and its parameters, are usually given in the technical documentation.

However, information about the out-of-band (i.e., at frequencies outside the operating band) characteristics of antennas in the vast majority of cases is lacking. As indicated in the literature [2]: "the out-of-band characteristics of antennas are currently not standardized, not controlled during their manufacture or certification, and are not given in the operational and other technical documentation." In a particular case, such characteristics can be determined experimentally using known methods for measuring antenna parameters.

It would seem that in the transmission mode the RED antenna system, playing the role of a frequency filter, will not allow the level of radiation at harmonics, which is dangerous from the point of view of electromagnetic compatibility (EMC), and thereby provide acceptable conditions for the operation of other radio equipment, both in the meter and in the decimeter range. 
However, if the levels of harmonics in relation to the power of the fundamental oscillation at the output of the radar transmitter are estimated, given, for example, in [3] (Table 1), then it becomes clear the need to study the directivity properties of antennas outside the operating frequency band and, in particular, at harmonic frequencies.

Note that the average radiation power in the operating frequency band can reach several hundred kilowatts. Therefore, at harmonics it reaches several watts. This indicates the possibility of interference with systems, both mobile communications and terrestrial television broadcasting in the decimeter wavelength range.

Table 1 - Relative maximum harmonic power level, dB

\begin{tabular}{|c|c|c|c|c|}
\hline \multirow{2}{*}{ Transmitter type } & \multicolumn{4}{|c|}{ Harmonic number } \\
\cline { 2 - 5 } & 2 & 3 & 4 & 5 \\
\hline Magnetron & 57 & 45 & 63 & 67 \\
\hline Klystronic & 38 & 57 & 56 & 59 \\
\hline
\end{tabular}

It can be noted that in the receiving mode, the radar antenna, along with the useful signal, is subject to interference if its directivity properties ensure the reception of radiation outside the main (operating) frequency band. This feature can lead, for example, to nonlinear effects in the receive path.

Therefore, if the spatial and frequency selectivity of the antenna array does not prevent this, then interference at harmonic frequencies can enter the input stages of the radar receiver. In this case, the EMC conditions also deteriorate.

To illustrate the above, Fig. 1 shows a modern domestic highly mobile radar MR-1 of the meter wavelength range with an antenna array formed from multi-element dipole antennas of the "wave channel" type. Such a radar is designed to detect all types of existing and prospective aerial objects, including stealth, unmanned and made using the "Stealth" technology [4]. It can be noted that the characteristics of vibrator antenna arrays in the presence of harmonic oscillations at their input in the radiation mode have not been sufficiently studied. Therefore, the question becomes relevant: can the directivity properties of vibrator antenna arrays contribute to the emission or reception of interference at the harmonics of the operating frequency?

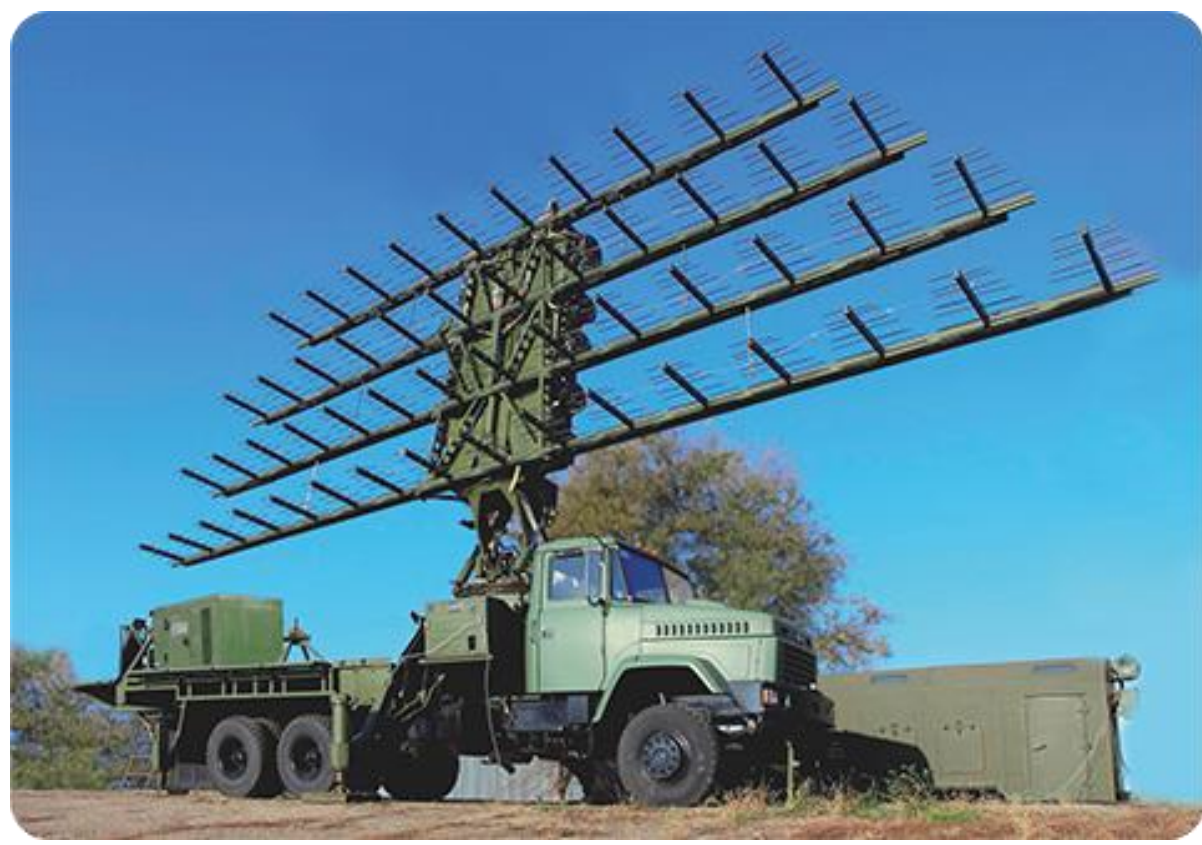

Figure 1 - Radar station type MR-1 
The purpose of this article is to analyze and compare the dependence of the spatial characteristics of the directivity of a vibrator antenna array at the operating frequency and at the frequencies of its harmonics.

Directivity properties of elements of vibrator antenna arrays. Before considering the directivity characteristics of the entire vibrator antenna array, it makes sense to first indicate the parameters of the elements from which it is formed and consider their directivity properties. Since these properties for the harmonics of the operating frequency of such elements have practically not been studied.

All subsequent calculations were performed in the Feko software environment [5] for the fundamental frequency $f_{0}=150 \mathrm{MHz}$ and for its four first harmonics $(300 \mathrm{MHz}, 450 \mathrm{MHz}$, $600 \mathrm{MHz}$ and $750 \mathrm{MHz}$ ).

The basis for the construction of a 25-element antenna array was chosen a Yagi antenna of the "wave channel" type (Fig. 2, a), the vibrators of which are made of flat ideally conducting plates $10 \mathrm{~mm}$ wide.

Its active element is a Pistolkors loop vibrator (Fig. 2, $b$ ), length $1_{\mathrm{a}}=0,49 \lambda_{0}$ (where: $\lambda_{0}$ is the wavelength in free space at a frequency $f_{0}$, the excitation source is placed in the middle of its lower part). The distance between the top and bottom of the loop vibrator is $0,02 \lambda_{0}$.

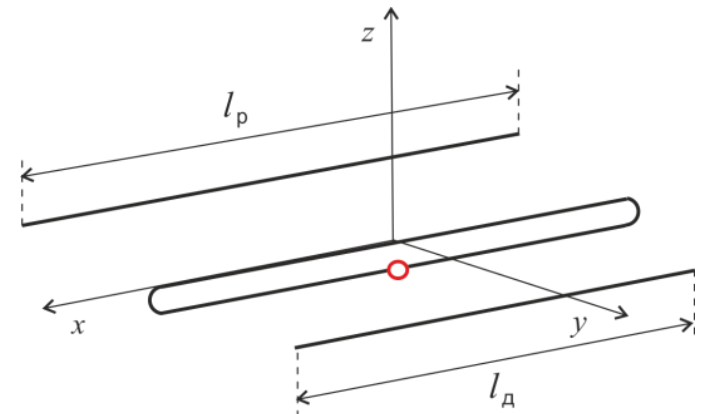

a)

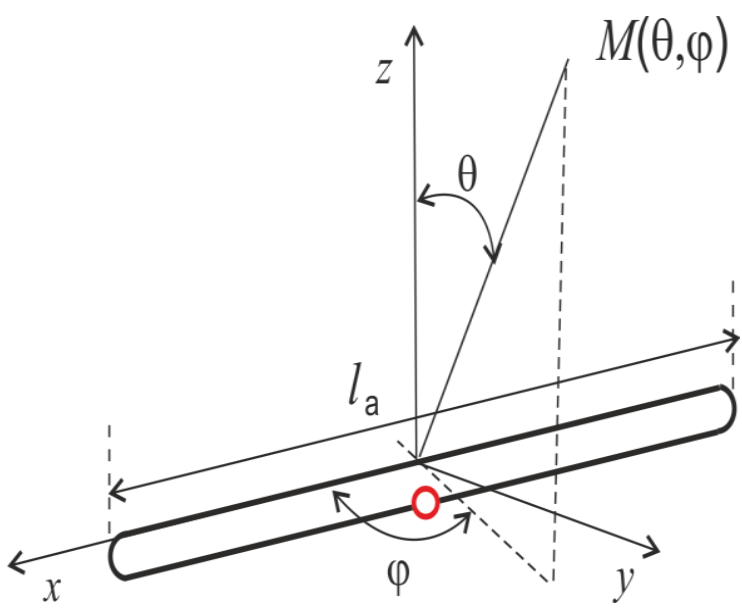

b)

Figure 2 - Investigated models of lattice elements

The length of the reflector of such an antenna $1_{p}=0,55 \lambda_{0}$, and the length of the director $1_{д}=0,45 \lambda_{0}$. The distances between the active vibrator and the reflector, as well as the director, are $0,2 \lambda_{0}$ and $0,15 \lambda_{0}$, respectively.

Diagrams characterizing the dependences of the DF coefficient of the loop vibrator on the angular coordinates are shown in Fig. 3, where, for comparison, each of these figures shows the dependence of the directivity at the fundamental frequency. 


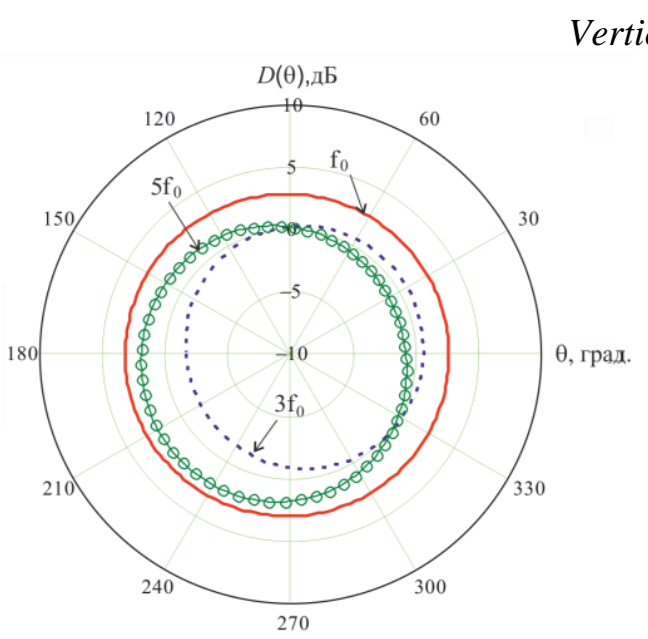

odd harmonics

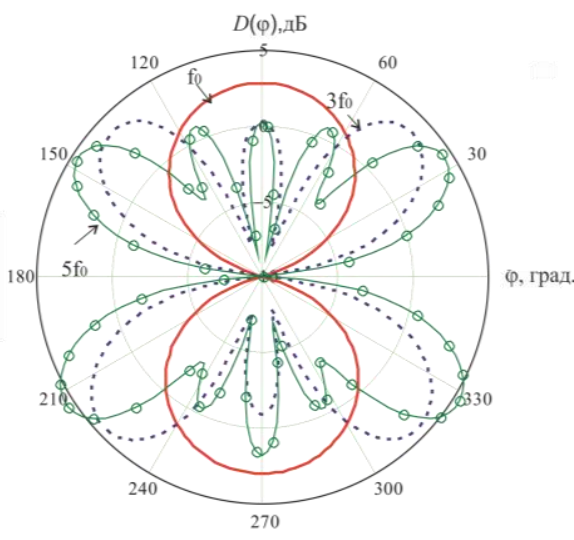

odd harmonics
Vertical plane

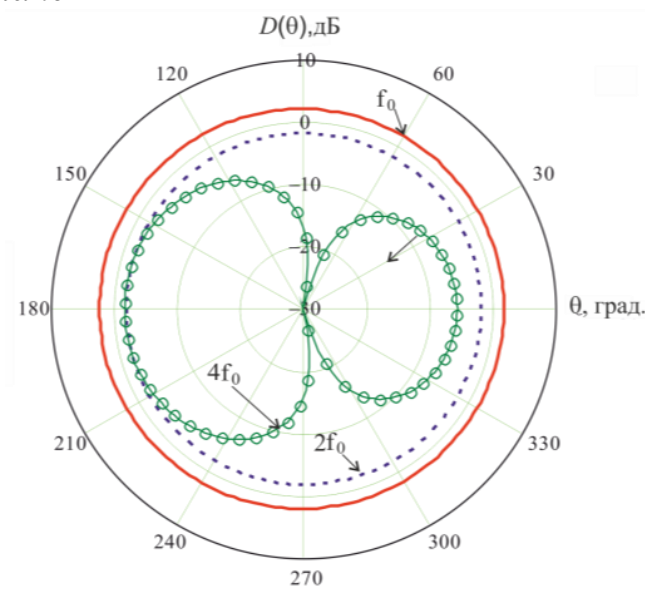

even harmonics

Horizontal plane

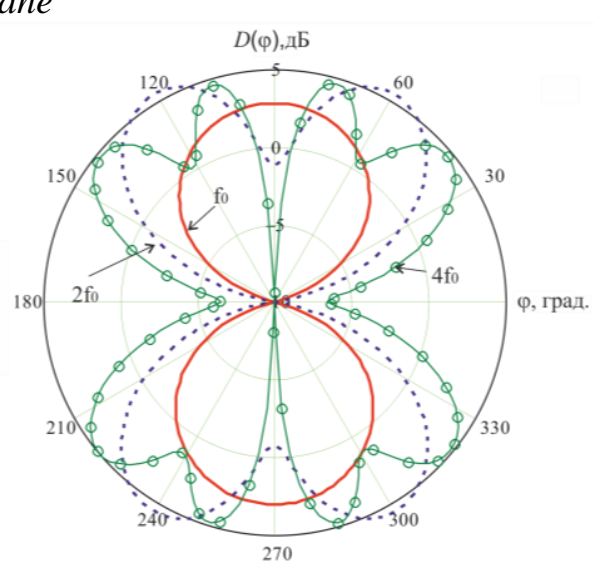

even harmonics

Figure 3 - Directivity coefficient of the loop vibrator

Comparing these diagrams plotted for the vertical plane, it can be noted that there is only a slight asymmetry at odd harmonics, while such asymmetry is sharply expressed at frequency ${ }_{4} f_{0}$. And this distinguishes this curve from the rest.

However, in the horizontal plane, at the harmonics, the appearance of several main lobes is observed, and the maximum directivity may be approximately $2 \ldots 3 \mathrm{~dB}$ higher than the maximum directivity at the fundamental frequency. At these frequencies, the main lobes are deflected from the normal to the vibrator axis, and the directivity in this direction is reduced and even drops to zero at the fourth harmonic.

All the noted features are manifested due to the fact that the dimensions of the vibrator (in relation to the wavelength) at the frequencies of the harmonics increase sharply. Consequently, the mutual influence of these parts and the distribution of currents in them change dramatically. The asymmetry of the active element in the vertical plane (since the excitation of the vibrator is carried out only in its lower part) leads, in particular, to the asymmetry of the diagrams in this plane.

Similar diagrams characterizing the dependences of the directivity of a three-element "wave channel" antenna are shown in Fig. 4. And here it is seen that in the vertical and in the horizontal plane, the directivity properties of such an antenna sharply deteriorate at the harmonics and the 
directivity in the back $\left(180 \geq \theta \leq 360^{\circ}\right)$ half-space increases. In the horizontal plane, several main lobes appear, deviating from the antenna axis. Moreover, in contrast to the diagrams of a single loop vibrator, in this plane the maximum value of the directivity in these lobes is noticeably less than the maximum directivity at the fundamental frequency.

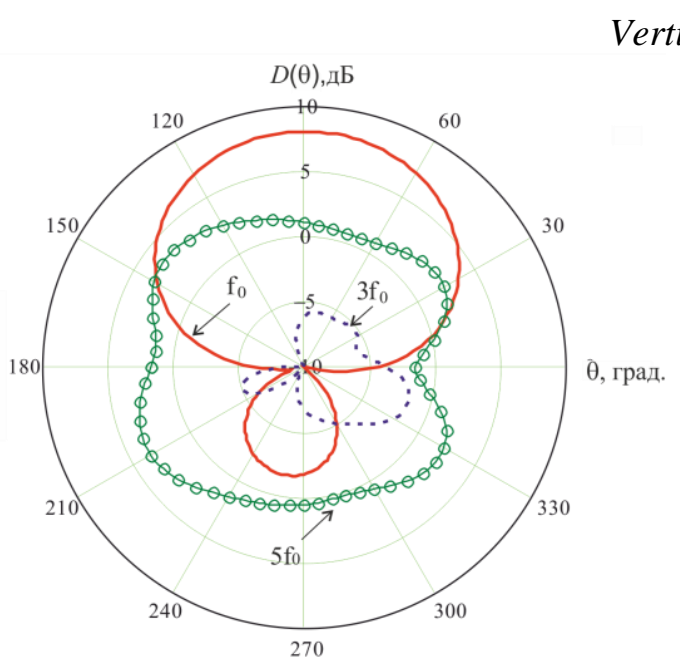

odd harmonics

\section{град.}

\section{Vertical plane}

a)

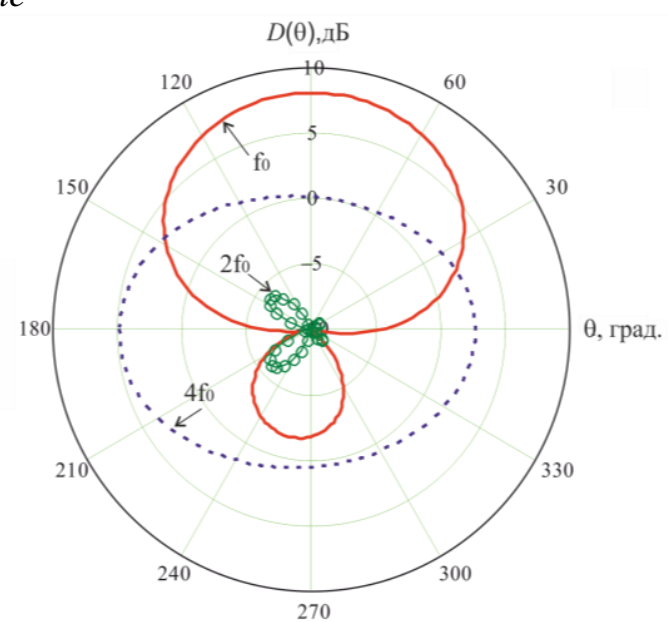

even harmonics

\section{Horizontal plane}

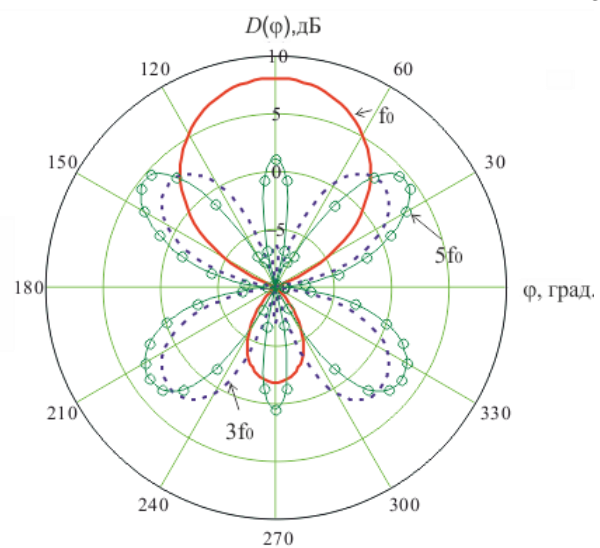

odd harmonics

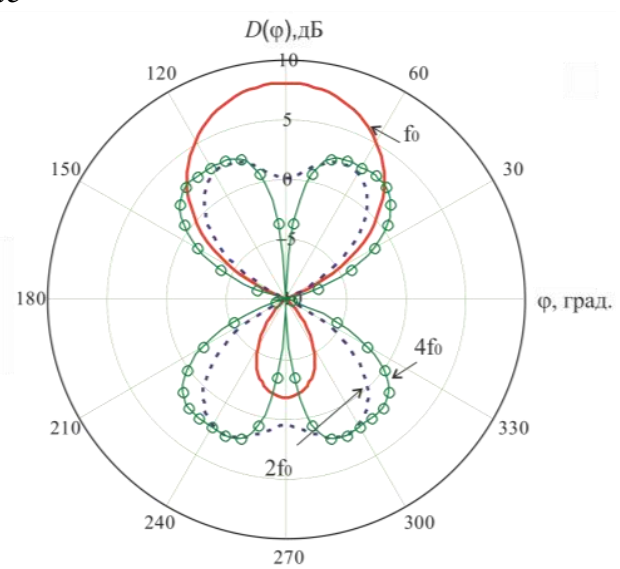

even harmonics

b)

Figure 4 - Directivity factor of a three-element antenna 
Directivity properties of the in-phase dipole antenna array. In the process of computer simulation, the directivity properties of an antenna array (Fig. 5), formed from $5 \times 5$ in-phase excited three-element antennas located in a homogeneous unlimited isotropic medium with

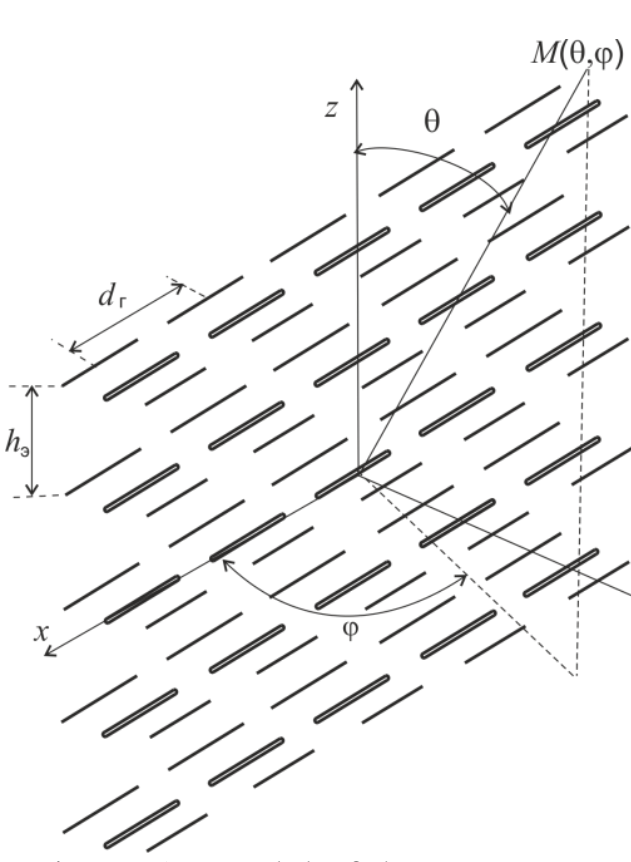

Figure 5 - Model of the antenna array parameters $\varepsilon_{0}, \mu_{0}$ corresponding to free space, were investigated. It can be assumed that the chosen geometry of the array will make it possible to estimate, from the point of view of EMC, the spatial properties that characterize vibrator antenna arrays with a different number of elements and geometry.

In the considered variant of the array geometry, the distance between the floors $h_{\ni}=0,5 \lambda_{0}$, the horizontal distance between the centers of adjacent antenna elements in each floor $\mathrm{d}_{\mathrm{r}}=0,75 \lambda_{0}$.

The dependences of the directivity of this grating on the angular coordinates are shown in Fig. 6. In the vertical plane, at the fifth harmonic ( $f=5 f_{0}$ ), the appearance of four main maxima at once is observed, the maximum value of the directivity in which is equal to the directivity in the main lobe at the fundamental frequency, both in the forward $\left(0 \geq \theta \leq 180^{\circ}\right)$ and in the rear half-space. Six more petals should be noted, which are somewhat inferior to them in terms of the maximum directivity. The remaining maxima in the lobes of the diagram at the fifth harmonic, as well as all maxima at the third harmonic, are about $10 \mathrm{~dB}$ less than at the fundamental frequency and can be disregarded.

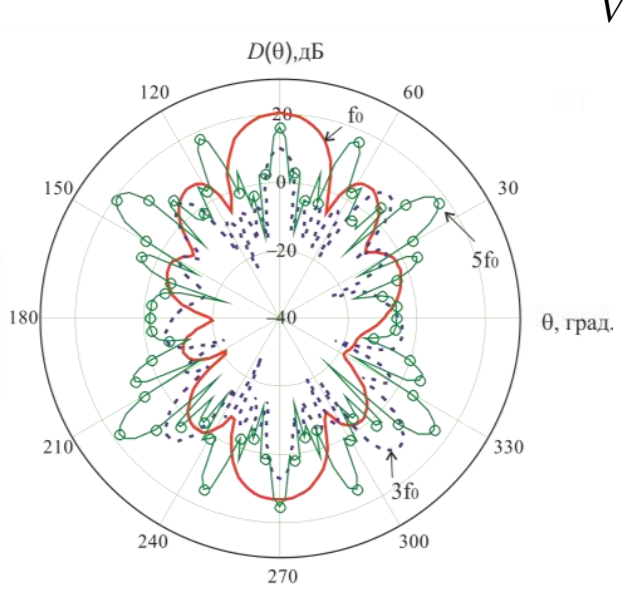

odd harmonics
Vertical plane

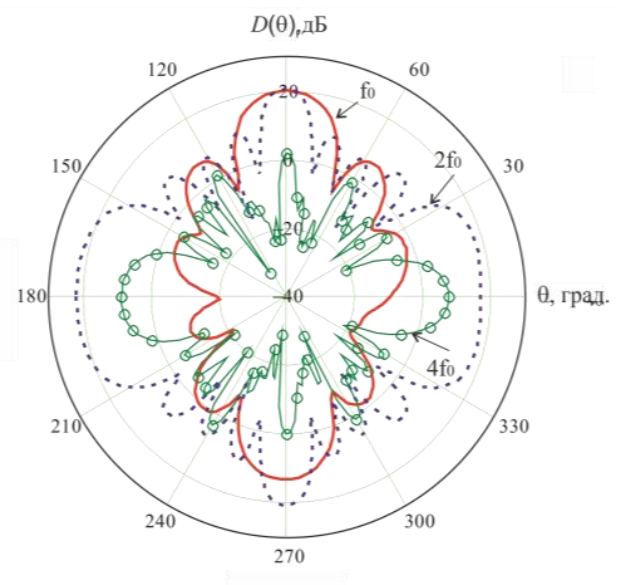

even harmonics

a) 


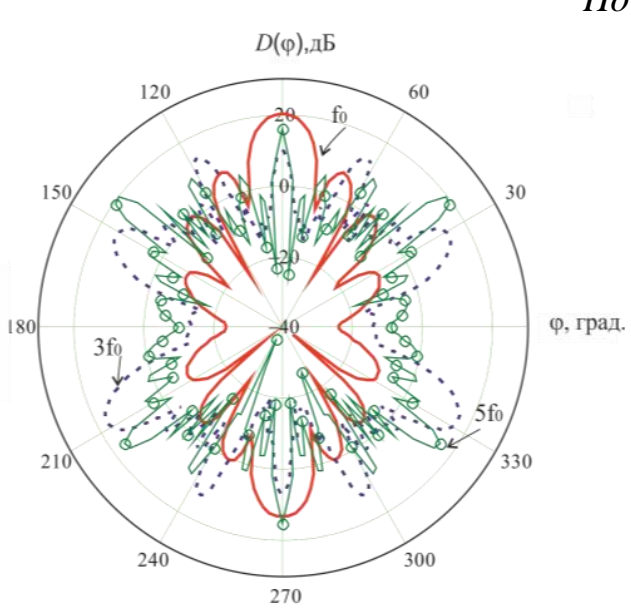

odd harmonics

\section{Horizontal plane}

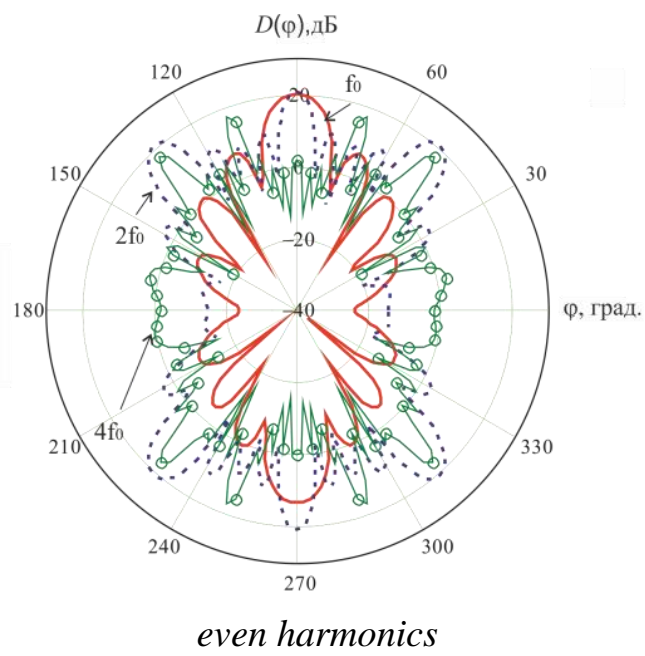

b)

Figure 6 - Coefficient of directional action of the lattice

But for even harmonics, the situation differs significantly from that considered earlier. Namely: at the second harmonic $\left(f=2 f_{0}\right)$,four main lobes in which the maximum of the directivity factor is the same as at the frequency $f_{0}$ are observed. Note that in the opposite direction $\left(\theta=270^{\circ}\right.$ ) the directivity maximum at a frequency $2 f_{0}$ is about $5 \mathrm{~dB}$ higher than a similar maximum at the fundamental frequency. That is, the EMC conditions in this direction noticeably deteriorate. The levels of the directivity maxima at the fourth harmonic in this plane are about $20 \mathrm{~dB}$ lower than the maximal directivity factor at the fundamental frequency; they can also be disregarded.

In the horizontal plane, for odd harmonics, is a similar picture. Here the directivity maxima prevail at the frequency $f=5 f_{0}$. However, in this plane, the maxima at the frequency $f=3 f_{0}$ also became more noticeable, the value of which is $3 \ldots .5 \mathrm{~dB}$ less than the maximum directivity at the fundamental frequency.

For even harmonics at $f=2 f_{0}$ (dashed line), six main maxima of the directivity figure with a level slightly higher than at $f=f_{0}$ are seen. And at this frequency there are already eight main maxima, the level of which is insignificantly (by $2 \ldots 3 \mathrm{~dB}$ ) less than the directivity of the main maximum at the frequency $f_{0}$.

Conclusions. The results of this article confirmed the validity of the assumptions that the directivity properties of vibrator antenna arrays can significantly affect the EMC conditions for harmonics of the fundamental frequency. At these frequencies, several main maxima appear in the directivity patterns, the level of directivity, in which it may even exceed the maximum directivity in the main lobe at the fundamental frequency. The noise immunity of the lattice in the rear hemisphere is noticeably worse.

Note that the results shown above refer to the case of in-phase excitation of active array elements (without power lines). However, the above diagrams can change significantly if there are series or mixed power supply lines. It can be assumed that the presence of bandpass filters in the input and output stages of the radar makes it possible to suppress harmonic interference, however, if these filters are made on the basis of transmission line segments, their properties at harmonic frequencies may be unpredictable. 
Further research in this direction can be focused on the study of the spatial characteristics of antenna arrays for various power supply schemes and filtering methods.

\section{REFERENCES:}

1. European Telecommunications Standards Institute [Electronic resourse] Accessmode: www. URL: https://www.etsi.org/technologies

2. Upravleniye radiochastotnym spektrom i elektromagnitnaya sovmestimost' radiosi-stem. Uchebn. posobiye / Pod red. d.t.n. prof. M.A. Bykhovskogo. M.: Eko-Trendz, (2006): 376.

3. Sedel'nikov YU.V. Elektromagnitnaya sovmestimost' radioelektronnykh sredstv / YU.V. Sedel'nikov // ZAO «Novoye znaniye ». Kazan'. (2006).

4. Nauchno-proizvodstvennyy kompleks „Iskra“. [Electronic resourse] Accessmode: www. URL: https:// iskra.zp.ua

5. Bankov S.Ye. Raschet izluchayemykh struktur s pomoshch'yu FEKO / S.Ye. Bankov, A.A. Kurushin. M.: ZAO «NPP «Rodnik», (2008): 245.

\section{ЛITEPATУРA:}

1. European Telecommunications Standards Institute. - Режим доступу: www. - URL: https://www.etsi.org/technologies

2. Керування радіочастотним спектром та електромагнітна сумісність радіосистем: навч. посіб., під ред. д.т.н. профр. М.А. Биховського. - М.: Еко-Трендз, 2006. - 376 с.

3. Седельніков Ю.В. Електромагнітна сумісність радіоелектронних засобів / Ю.В. Седельніков // ЗАТ «Нове знання». - Казань, 2006.

4. Науково-виробничний комплекс „Іскра“. - Режим доступу: www. URL: https:// iskra.zp.ua

5. Банков С.Є. Розрахунок випромінюючих структур із застосуванням FEKO / С.Є. Банков, О.А. Курушин. - М.: ЗАТ «НВК «Родник», 2008. - 245 с.

DOI 10.33243/2518-7139-2020-1-2-40-49 